\title{
Laju Pertumbuhan Larva Ikan Koan (Ctenopharyngodon idella) Dengan Kepadatan Yang Berbeda
}

\author{
${ }^{1}$ Agung Nugroho, ${ }^{2}$ Muhammad Sugihartono, dan ${ }^{2}$ Muarofah Ghofur \\ ${ }^{1}$ Alumni Program Studi Budidaya Perairan, Fakultas Pertanian Universitas Batanghari \\ ${ }^{2}$ Program Studi Budidaya Perairan, Fakultas Pertanian Universitas Batanghari \\ Jl.Slamet Riyadi, Broni Jambi. 36122. Telp. +62074160103 \\ ${ }^{1}$ Email Korespondensi : agungnugrohojmb@gmail.com
}

\begin{abstract}
The growth of an individual is a tissue increase as a result of mitotic cell division. Growth is influenced by two fakors, namely intrinsic (deep) and extrinsic (outer) factors. Intrinsic factors include heredity, age/size, resistance to disease and food-utilising ability, while extrinsic factors include physical and chemical properties of the water and biological components such as food availability and competition. In addition fish growth is also influenced by dense dispersion. Solid dispersion is one of the cultivation aspects that need to be known because it determines the pace of growth, and as a supporting production success until it reaches the next phase. Therefore, to know the optimal density of larvae conducted the research on optimal solid tebar with treatment 5 tail/Liter of water, 10 tails/Liter of water, 15 tails/Liter of water, 20 tails/liter of water. The results showed on the treatment of 5 tails/liters of airflow capable of generating a daily growth rate of $5.41 \%$.
\end{abstract}

Keywords : Larvae, density, growth

Abstrak. Pertumbuhan suatu individu adalah pertambahan jaringan akibat dari pembelahan sel secara mitosis. Pertumbuhan dipengaruhi oleh dua fakor yaitu faktor intrinsik (dalam) dan ekstrinsik (luar). Faktor intrinsik meliputi sifat keturunan, umur/ukuran, ketahanan terhadap penyakit dan kemampuan memanfaatkan makanan, sedangkan faktor ekstrinsik meliputi sifat fisik dan kimiawi perairan serta komponen hayati seperti ketersediaan makanan dan kompetisi.Selain itu pertumbuhan ikan juga dipengaruhi oleh padat penebaran. Padat penebaran merupakan satu diantara aspek budidaya yang perlu diketahui karena menentukan laju pertumbuhan, dan sebagai penunjang keberhasilan produksi hingga mencapai fase selanjutnya. Oleh karena itu, untuk mengetahui kepadatan optimal larva dilakukan penelitian mengenai padat tebar optimal dengan perlakuan 5 ekor/liter air, 10 ekor/liter air, 15 ekor/liter air, 20 ekor/liter air. Hasil penelitian menunjukkan pada perlakuan 5 ekor/liter airmampu menghasilkan laju pertumbuhan harian sebesar $5.41 \%$

Kata kunci : Larva Koan, Kepadatan,Pertumbuhan

\section{PENDAHULUAN}

Ikan koan (Ctenopharyngodon idella) adalah ikan introduksi yang berasal dari Cina yang didatangkan ke Indonesia pada tahun 1915 dengan tujuan untuk dibudidayakan. Ikan ini merupakan salah satu jenis ikan ekonomis penting dalam budidaya perikanan air tawar karena ikan ini memiliki rasa yang enak dengan dagingnya yang berwarna putih, sangat kenyal dan tebal di seluruh bagian tubuhnya. Selain rasanya yang enak ikan koan biasanya dimanfaatkan sebagai pengendali gulma, sehingga kita memperoleh manfaat yang lain selain untuk dikonsumsi. (Kordi, 2009 dalam Babo, et al 2013).

Upaya dalam memenuhi kebutuhan konsumsi masyarakat akan ikan koan yang semakin meningkat, sehingga membuat intensitas penangkapan ikan koan dari alam semakin tinggi. Untuk mengatasi hal tersebut sektor budidaya ikan koan menjadi solusinya terutama pada kegiatan pembesaran untuk ukuran konsumsi. Proses kegiatan pembesaran pada masa budidaya membutuhkan stok benih yang berkualitas dan memadai. Oleh karena itu untuk meningkatkan produksi budidaya ikan koan perlu adanya optimalisasi pemeliharaan 
ikan koan antara lain dengan meningkatkan padat penebaran pada masa pemeliharaan larva ikan koan pada lingkungan yang terkontrol.

Sehubungan dengan ini peningkatan padat penebaran ikan harus sejalan dengan daya dukung lahan pemeliharaan (Carrying capacity). Apabila salah dalam menentukan padat penebaran ikan yang akan dibudidayakan justru akan menjadi bumerang bagi pembudidaya itu sendiri. Setiawan (2009) menyatakan bahwa peningkatan kepadatan atau tingkat padat tebar yang tidak sesuai akan berakibat terganggunya proses fisiologis dan tingkah laku ikan terhadap ruang gerak yang pada akhirnya dapat menurunkan kondisi kesehatan dan fisiologis ikan akibatnya pemanfaatan makanan, pertumbuhan, dan kelangsungan hidup mengalami penurunan. Stress akan meningkat cepat ketika batas daya tahan ikan telah tercapai atau terlewati. Dampak stress ini mengakibatkan daya tahan tubuh ikan menurun dan selanjutnya terjadi kematian.

Penelitian ini bertujuan untuk mengetahui padat tebar yang optimal untuk kelangsungan hidup dan pertumbuhan larva ikan koan $(C$. idella). Penelitian ini diharapkan dapat memberikan informasi tentang padat tebar larva ikan koan $(C$. idella)yang optimal pada lingkungan yang terkontrol

\section{METODOLOGI PENELITIAN}

Penelitian ini dilakukan pada unit budidaya dengan kondisi tertutup (Hatchery) berlokasi di Balai Benih Ikan Daerah Instalasi Telanaipura Provinsi Jambi. Larva yang digunakan adalah larva ikan koan ( $C$ idella ) yang berumur 5-7 hari. Yang kemudian dipelihara selama 30 hari dengan wadah akuarium dan diberi aerasi untuk ketersedian oksigen. Larva dipelihara dengan kepadatan yang berbeda . penelitian ini disusun dengan Rancangan Acak Lengkap (RAL). Perlakuan yang diuji adalah A: 5 ekor/liter air B: 10 ekor/liter air C: 15 ekor/liter air D: 20 ekor/liter air. Masing-masing terdiri tiga kali ulangan. Selama penelitian larva diberi makan artemia spsampai 10 hari pertama dan diteruskan dengan pakan cacing sutera Tubifex spselama 10 kedua dan pelet komersil hingga akhir penelitian. Pemberian pakan diberikan secara kenyang sebanyak lima kali sehari pada pukul 07.00, 11.00, 15.00, 19.00, dan 23.00. Monitoring kualitas air dilakukan pada awal, tengah dan akhir penelitian. Laju Pertumbuhan spesifik (specific growth rate, SGR) adalah laju pertumbuhan bobot harian ikan, yang dihitung dengan rumus Steffens (1989) :

$$
\text { SGR }=\frac{\text { In } W_{t}-\text { In } W_{o}}{T} X 100 \%
$$

Keterangan :

$\begin{array}{ll}\text { SGR } & \text { : Laju pertumbuhan spesifik }(\%) \\ \mathrm{T} & \text { : Waktu Pemeliharaan (hari) } \\ \mathrm{Wt} & \text { : Bobot rata-rata ikan pada akhir pemeliharaan (gram/ekor) } \\ \mathrm{W} & \text { : Bobot rata-rata ikan pada awal pemeliharaan (gram/ekor) }\end{array}$

Sebagai data penunjang parameter kualitas air yang dimonitor antara lain berupa suhu, $\mathrm{pH}, \mathrm{DO}$, $\mathrm{CO}_{2}, \mathrm{NH}_{3}$. Data yang diperoleh dianalisis secara statistik menggunakan sidik ragam (ANOVA) dengan program SPSS 20 dan ditampilkan dengan bentuk grafik dan tabel serta data lain yang dianalisis secara deskriptif.

\section{HASIL DAN PEMBAHASAN}

Kepadatan tinggi akan mempersempit ruang gerak sehingga berdampak terhadap peningkatan kompetisi dalam memperoleh pakan dan oksigen. Kekurangan pakan akan memperlambat laju pertumbuhan ikan dan ruang gerak juga merupakan faktor luar yang mempengaruhi laju pertumbuhan spesifik, dengan adanya ruang gerak yang cukup luas ikan dapat bergerak secara maksimal. padat penebaran yang tinggi ikan mempunyai daya saing di dalam memanfaatkan makanan, dan ruang gerak, sehingga akan mempengaruhi laju pertumbuhan ikan tersebut. Hal ini menunjukkan bahwa masing-masing ikan memiliki jumlah padat 
penebaran tertentu. Penyebab lainnya adalah diduga pada kepadatan tinggi ikan akan bersaing untuk memperoleh oksigen terlarut Rahmat (2010) dalam Azhari, et al (2017).

Berdasarkan hasil penelitian padat tebar yang optimal untuk kelangsungan hidup dan pertumbuhan larva ikan koan (C. idella) selama 40 hari, didapatkan jumlah tingkat kelangsungan hidup, pertambahan panjang dan bobot serta laju pertumbuhan spesifik (SGR) ikan koan pada setiap perlakuan. Hasil rata - rata dari masing - masing parameter yang diuji dalam penelitian tersebut dapat dilihat pada Tabel 1 berikut ini.

Tabel 1. Hasil parameter uji penelitian ikan koan dengan padat tebar yang berbeda

\begin{tabular}{cccccc}
\hline \multirow{2}{*}{ NO } & \multirow{2}{*}{ Parameter } & \multicolumn{4}{c}{ Perlakuan } \\
\cline { 3 - 6 } & & $\mathrm{A}$ & $\mathrm{B}$ & $\mathrm{C}$ & $\mathrm{D}$ \\
\hline 1 & Laju Pertumbuhan (SGR) & $5.41^{\mathrm{b}}$ & $4.05^{\mathrm{ab}}$ & $3.3^{\mathrm{ab}}$ & $3^{\mathrm{a}}$ \\
\hline
\end{tabular}

Dari asil rata-rata laju pertumbuhan spesifik (SGR) pada masing-masing perlakuan dapat dilihat pada gambar di bawah ini.

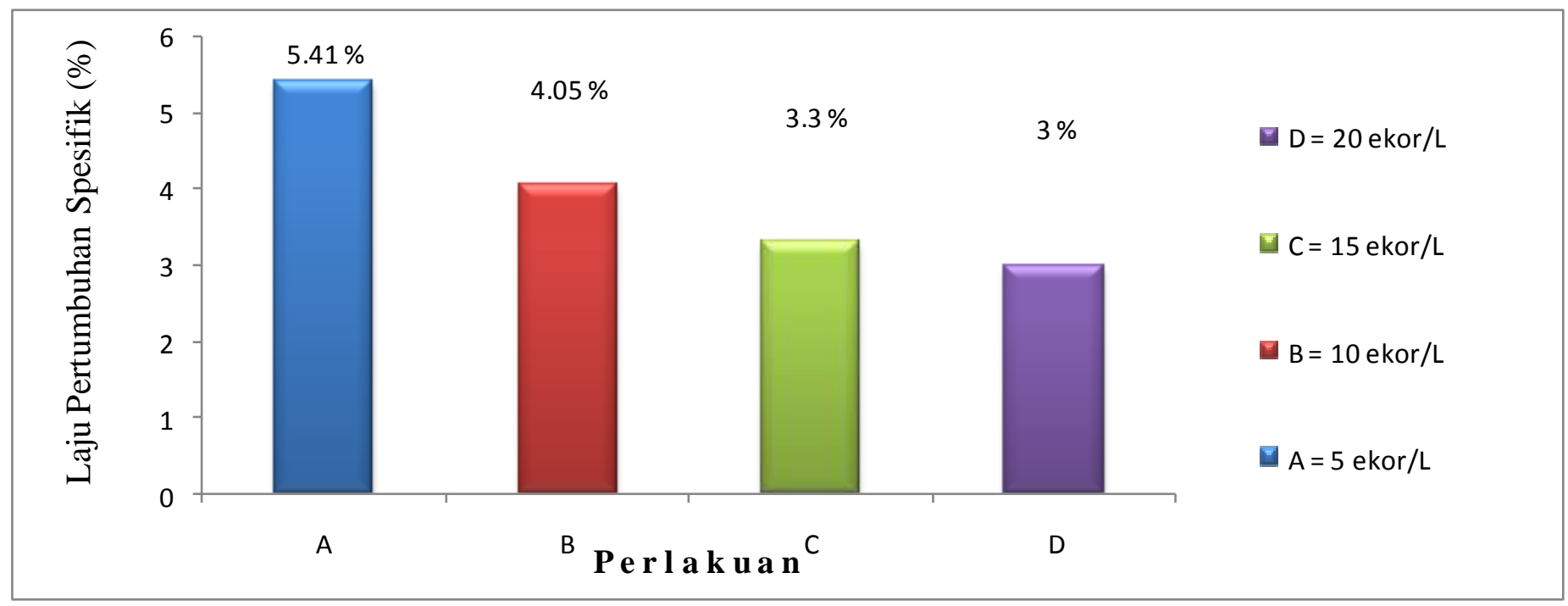

Gambar 1. Tingkat pertumbuhan spesifik (SGR) (\%) pada padat tebar berbeda.

Dari Gambar di atas terlihat jelas bahwa perlakuan dengan padat tebar yang tinggi dapat menyebabkan laju pertumbuhan spesifik menjadi rendah.Pada perlakuan D dengan tingkat padat tebar yang tertinggi yaitu 20 ekor/L laju pertumbuhan spesifik (SGR) hanya sebesar 3\% perhari. Hal ini berbanding terbalik dengan perlakuan A yang tingkat padat tebar terendah yaitu 5 ekor/L mampu menghasilkan laju pertumbuhan harian sebesar $5.41 \%$ per hari. 
Tabel 2. Hasil Pengukuran Parameter Kualitas Air setiap perlakuan

\begin{tabular}{|c|c|c|c|c|c|c|}
\hline \multirow{3}{*}{ No } & \multirow{3}{*}{ Parameter Kualitas Air } & \multicolumn{4}{|c|}{ Akuarium Perlakuan } & \multirow{3}{*}{ Kisaran Optimum } \\
\hline & & \multicolumn{4}{|c|}{ Nilai / Kisaran } & \\
\hline & & A & $\mathrm{B}$ & $\mathrm{C}$ & $\mathrm{D}$ & \\
\hline 1 & Suhu $\left({ }^{0} \mathrm{C}\right)$ & $27-28$ & $27-28.1$ & $27-28$ & $27-28$ & $25-32{ }^{0} \mathrm{C}$ (Boyd, 1982) \\
\hline 2 & $\mathrm{pH}$ & $5.7-6.3$ & $5.7-6.3$ & $5.7-6$ & $5.1-5.9$ & 4-8 (Syulfia et al, 2015) \\
\hline 3 & $\mathrm{DO}(\mathrm{mg} / \mathrm{l})$ & $5-6.6$ & $5-6.7$ & $5-6.5$ & $5-6.2$ & >3 mg (Zonneveld et al, 1991) \\
\hline 4 & $\mathrm{CO}_{2}(\mathrm{mg} / \mathrm{l})$ & $2-4.6$ & $2.2-4.6$ & $3.5-4.6$ & $4.6-5.1$ & $<10 \mathrm{mg}$ (Zonneveld et al, 1991) \\
\hline 5 & Ammonia (mg/l) & $0-0.0013$ & $0-0.0019$ & $0-0.0086$ & $0-0.017$ & $<0,1$ (Boyd, 1990) \\
\hline
\end{tabular}

Pada tabel 2 tertera data kualitas air selama penelitian pada setiap perlakuan.

Secara umum parameter kualitas air tersebut masih memenuhi standar baku mutu bagi kehidupan ikan koan. Suhu media pemeliharaan ikan koan selama penelitian berkisar antara $27^{\circ} \mathrm{C}-28.1^{\circ} \mathrm{C}$ (Tabel 4 ) sehingga masih dalam kisaran normal (Boyd, 1982). Suhu merupakan salah satu faktor fisika perairan yang sangat penting dan berpengaruh bagi pertumbuhan ikan. Ikan merupakan hewan poikilothermal yaitu hewan yang memiliki suhu tubuh yang sama dengan suhu lingkungan sekitarnya. Ikan merupakan hewan berdarah dingin sehingga suhu berpengaruh langsung pada laju metabolisme ikan. Perubahan suhu dapat menyebabkan perubahan laju metabolisme ikan, semakin tinggi suhu media maka laju metabolisme ikan juga akan meningkat sehingga nafsu makan ikan meningkat.

Derajat keasaman $(\mathrm{pH})$ adalah suatu konsentrasi ion hidrogen dan menunjukan air tersebut bersifat asam atau basa. Keasaman ( $\mathrm{pH}$ ) yang suboptimal berakibat buruk pada spesies kultur dan menyebabkan ikan stres, mudah terserang penyakit, produktivitas dan pertumbuhan rendah. Pada akhir penelitian perlakuan D menghasilkan nilai pH yang terendah yaitu 5,1 (asam) hal ini diduga disebabkan oleh tingginya jumlah padat tebar ikan yang dipelihara sehingga sisa metabolisme yang dihasilkan oleh ikan pun banyak dan hal ini menyebabkan $\mathrm{pH}$ air menjadi rendah atau bersifat asam. Kisaran $\mathrm{pH}$ air media pemeliharaan ikan koan selama penelitian berkisar anatar 5.1 - 6.3. Kisaran ini dapat ditoleril oleh ikan koan. Karena ikan koan dapat bertahan hidup pada kisaran pH antara 5.0 - 9.0, (Shireman dan Smith, 1983 dalam Cudmore dan Mandrak, 2004).

Oksigen terlarut adalah oksigen dalam bentuk terlarut didalam air karena tidak semua ikan dapat mengambil oksigen secara difusi langsung dari udara.Tingkat konsumsi oksigen ikan bervariasi tergantung pada suhu, konsentrasi oksigen terlarut, ukuran ikan, tingkat aktivitas, waktu setelah pemberian pakan dan lain sebagainya.Tingkat metabolisme juga bervariasi antar spesies dan dibatasi oleh rendahnya kandungan oksigen yang tersedia. Umumnya, ikan kecil akan mengkonsumsi oksigen per berat badan lebih banyak dibandingkan ikan besar dari satu spesies. Oksigen terlarut dibutuhkan oleh semua jasad untuk pernafasan, proses metabolisme atau pertukaran zat yang kemudian menghasilkan energi untuk pertumbuhan dan perkembangbiakan juga untuk oksidasi bahan-bahan organik dan anorganik dalam proses aerobic .Nilai kandungan oksigen terlarut (DO) pada media pemeliharaan ikan koan dari awal hingga akhir penelitian berkisar antara $5-6.7 \mathrm{mg} / \mathrm{l}$. Kisaran ini masih berada dalam kisaran yang mendukung untuk kehidupan ikan.Kandungan oksigenterlarut yang ideal di dalam air untuk budidayaikan adalah >3,00 mg/l (Zonneveld et al, 1991).

Nilai korbondioksida selama penelitian berkisar antara antara $2-5.1 \mathrm{mg} / \mathrm{l}$ nilai ini masih dalam kondisi yang normal untuk pertumbuhan ikan koan.Menurut Effendi (2002), karbondioksida merupakan hasil buangan akibat adanya proses pernafasan mahkluk hidup. Pada konsentrasi tinggi (> $10 \mathrm{mg} / \mathrm{l})$, karbondioksida dapat beracun karena keberadaannya di dalam darah dapat menekan aktivitas pernapasan ikan dan menghambat pengikatan oksigen oleh hemoglobin sehingga dapat membuat ikan menjadi stress.Kandungan karbondioksida didalam air untuk pembesaran ikan sebaiknya kurang dari $10 \mathrm{mg} /$ liter (Zonneveld et al, (1991). 
Menurut Zonneveld et al (1991), ammonia merupakan hasil akhir dari proses metabolisme protein.Konsentrasi ammonia selama penelitian berkisar antara 0- 0,017 $\mathrm{mg} / \mathrm{l}$, pada semua perlakuan kisaran nilai ammonia masih berada dalam konsentrasi yang bisa ditolerir oleh ikan. Pada perlakuan D dengan padat tebar yang tinggi akan menghasilkan ammonia yang tinggi karena sisa metabolisme yang dihasilkan lebih banyak dibanding perlakuan yang lain. Sisa metabolisme dapat menyebabkan naiknya ammonia di dalam air seperti sisa pakan dan kotoran ikan Kadar ammonia yang tinggi dapat menyebabkan naiknya kadar $\mathrm{pH}$ darah dan memiliki efek yang merugikan pada reaksi berbagai enzim dan stabilitas membran. Efek negatif tersebut meliputi kerusakan insang, pengurangan kapasitas darah dalam membawa oksigen serta kerusakan histologi pada sel darah merah (Boyd, 1998).

\section{KESIMPULAN}

kepadatan 5 - 20 ekor/L memberikan hasil yang berbedaterhadap laju Pertumbuhan spesifik ikan koan ( $C$ idella ), perlakuan yang menunjukan hasil terbaik adalah A. (5 ekor/Liter) dengan hasil panjang $(5.96 \mathrm{~cm})$, bobot (2.23 gr).

\section{DAFTAR PUSTAKA}

Babo, D., J. Sampekalo dan H. Pangkey. 2013. Pengaruh Beberapa Jenis Pakan Hijauan Terhadap Pertumbuhan Ikan Koan(Stenopharyngodon idella). Budidaya Perairan. UNSRAT. Manado. Vol. 1 No. 3: $1-6$

Boyd. 1982. Water Quality Management for Pond Fish Culture. Elsevier Scientific Publishing Company. Amsterdam-Oxford. New York. 585 p.

Cudmore B, Mandrak NE. 2004. Biological Synopsis of Grass Carp (Stenopharyngodon idella). Canadian Manuscript Report of Fisheries and Aquatic Sciences 2705. Burlington-Kanada.

Effendi. H. 2002. Telaah Kualitas Air Bagi Pengelola Sumber Daya Dan Lingkungan Perairan.Yayasan Pustaka Nusantara. Yogyakarta. $258 \mathrm{Hal}$

Setiawan, B. 2009. Pengaruh Padat Penebaran 1, 2, dan 3 Ekor/L Terhadap Kelangsungan Hidup dan Pertumbuhan Benih Ikan Maanvis Pterophyllum scalare. Skripsi. Program Studi Teknologi dan Manajemen Akuakultur. Departemen Budidaya Perairan. Fakultas Perikanan dan Ilmu Kelautan. Institut Pertanian Bogor. Bogor.

Zonneveld. N, E. A. Huisman, J. H. Boon. 1991. Prinsip-prinsip budidaya ikan. Gramedia Pustaka Umum. Jakarta. 